\title{
広域照射による光放射圧を用いた簡易微粒子輸送法
}

\section{Simple method of particle transportation by optical radiation pressure with large area irradiation ○ 神足英春（東理大院），正 元祐昌度（東理大工）}

\begin{abstract}
Hideharu Kotari, Tokyo University of Science, 6-3-1 Niijuku, Katsushika-ku, Tokyo, 125-8585 Japan Masahiro Motosuke, Tokyo University of Science

This paper presents a novel and simple method of the particle sorting by optical force with large area irradiation which enables damageless handling with low energy density. Particle sorting in a microchannel is promising technology to be widely used in the field of chemical and medical analysis. However, a strongly focused irradiation of laser beam as in optical tweezers would yield serious damage to the device and sample due to the high energy density. Our alternative sorting system includes a microfluidic device with long channel in which particles flowing inside receive low energy light. Enough long retention distance of particle depending on its size is achieved in the downstream region of the device. We have successfully demonstrated our concept of the simple particle sorting system which could expand the use of the optical-based particle manipulation technique.
\end{abstract}

Key Words: Particle sorting, Optical radiation pressure, Microfluidics, Large area irradiation, Low energy density

\section{1. 序論}

近年, 医療診断や環境分析などの分野においてマイクロデ バイスの利用が検討されているが, デバイス内での微粒子の 輸送は極めて重要な技術である.特に, 光を用いた微粒子の 輸送は, 非接触・非侵襲操作が可能であることから, 内部操作 が困難なマイクロ流体デバイスへの適応が望まれる(1). 光が 粒子に照射されると,粒子表面や内部での反射や屈折に伴う 運動量変化が生じ, 結果として粒子にはこの変化に起因した 力である光放射圧が作用する. 光放射圧は, 光波進行方向成 分の散乱力と垂直成分の勾配力に分けられるが, 生化学分野 で一般的に用いられている光ピンセットでは, 高 NA レンズ でスポット状に集光した高密度光の焦点位置に作用する勾 配力を利用して粒子を捕捉する. 光ピンセットは選択的な粒 子操作が可能である一方, 高コヒーレント光を用いた高精度 な光軸の位置決めを必要とするため, 顕微鏡内での実験を行 う必要があり,ポータブルセンサへの応用が困難である.ま た高密度・局所光を照射するため, デバイスの損傷や粒子へ の影響が奬念される(2).

そこで, 本研究では, 光照射方法の新しい提案として, 太 陽光や高出力ランプのような低密度かつ低コヒーレント光 でも可能な粒子輸送システムを構筑する. 粒子輸送の原理に は, 散乱力支配の駆動力を粒子に作用させ, 光の進行方向一 と粒子を輸送する光泳動を用いる. 長距離流路と低密度光照 射を組み合わせることで, 十分な粒子移動距離を得ることが できるシステムを構築した. 本稿では, その原理確認のため に実施した実験及び結果について示す.

\section{2. 広域 - 低密度光照射}

流れに垂直かつ広域な光を粒子に照射することで, 勾配力 が相殺され, 散乱力のみが粒子に作用する.そのため, 図 1 の ように粒子は光波進行方向への力を受けて移動する.粒子の 移動距離は粒子が受ける散乱力と流体から受ける粘性抵抗 とのつりあいから以下の式で求まる(3).

$$
\Delta=\int \frac{n d I l}{12 \eta c U} Q_{s} d \theta
$$

ここで, $\Delta$ は粒子移動距離, $n$ は液体の屈折率, $d$ は粒径, $I$ は 光密度, $l$ は流路の長さ, $\eta$ は液体の粘性率, $c$ は光速, $U$ は主 流速度, $Q_{s}$ は単一光線が及ぼす散乱効果, $\theta$ は粒子表面の入 射角を示す。
式(1)から, 粒子の移動距離は, 光密度と流路長さ共に比例 関係にあることがわかる. そのため, 単位時間当たりに粒子 が受ける光放射圧は光密度に依存するものの, 照射光の総エ ネルギ量一定の下では, 粒子の移動距離は光密度に依存しな いつまり低密度光でも粒子が長時閒光を受けるように広域 照射を行うことで, 高密度・局所照射の場合と同等な粒子移 動距離を得ることが可能である.

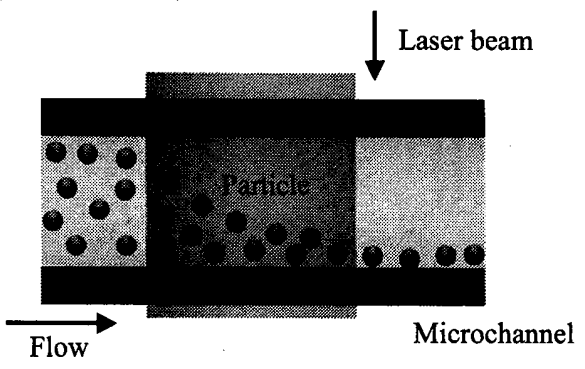

Fig. 1 Particle transportation by large and uniform laser irradiation

\section{3. 実験装置}

図 2 に光照射システムの概略図を示す. 流路は幅, 高さ共に $50 \mu \mathrm{m}$ とし， softlithography によって作製された PDMS (polydimethylsioxane) 製の流路パターンとガラス板で構成さ れる.デバイス内 $25 \mathrm{~mm} \times 20 \mathrm{~mm}$ の領域に長さ $10 \mathrm{~cm}$ の流路 を設け，その全域に光が照射されるシステムを構築した.ま た, 流路長さ $15 \mathrm{~mm}$ の短距離流路デバイスを比較のために 作成した.

光照射による粒子輸送を定量的に評価するために, 光照射 領域直後の下流領域にお引る粒子の挙動を, 光照射面と垂直 な方向から計測を行った，その際，流路と観察面との厚さを $120 \mu \mathrm{m}$ と薄くした PDMS 壁を介して観察を行うことで,より 鮮明な粒子画像を取得している。

駆動光源には, PDMS の吸光度を考慮して, 波長 $1064 \mathrm{~nm}$ の近赤外 DPSS (diode pumped solid state) レーザを用いた. ま た,レーザ光を凹レンズで拡大することで, デバイス全体に 低密度光を照射させる. 粒子には直径 2，5 $\mu \mathrm{m}$ の蛍光ポリス チレンを用い, 励起光により誘起された粒子の蛍光発光の輝 度值パターンに対して,ガウス分布を用いたテンプレート マッチング(4)で位置情報を抽出して評価を行った。 


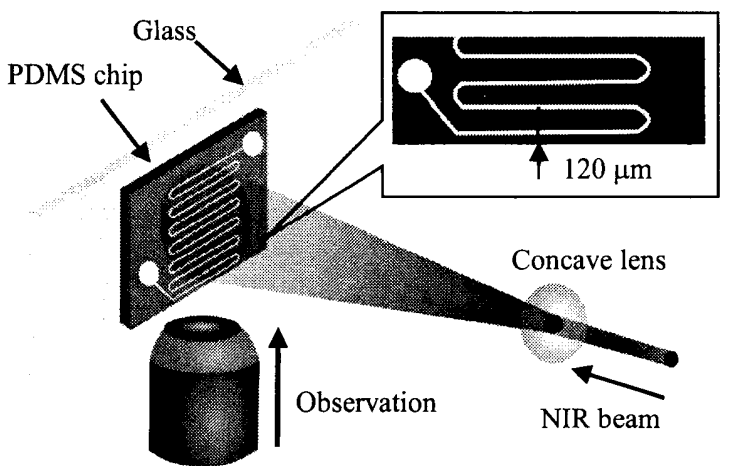

Fig. 2 Schematic diagram of experimental setup

\section{4. 実験結果}

4-1 低密度光を用いた光放射圧による粒子移動

流路長さ $10 \mathrm{~cm}$ の長距離流路を用いて粒子輸送の確認を 行った. 粒径 $5 \mu \mathrm{m}$ の粒子を流し， $8.5 \mathrm{~mW} / \mathrm{mm}^{2}$ の低密度光 を照射した際の粒子画像とスパン方向における粒子数分布 を図 3 に示す.光未照射時には，粒子は均一に分布している のに対し, 光照射時では流路壁面へと粒子が集積しているこ とが確認できる.よって散乱力によって粒子が光照射進行方 向に移動されたことから，本システムにおける粒子輸送の有 効性を確認した。
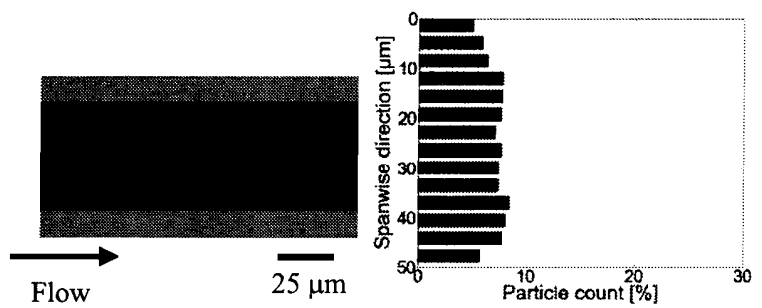

(a) Laser off
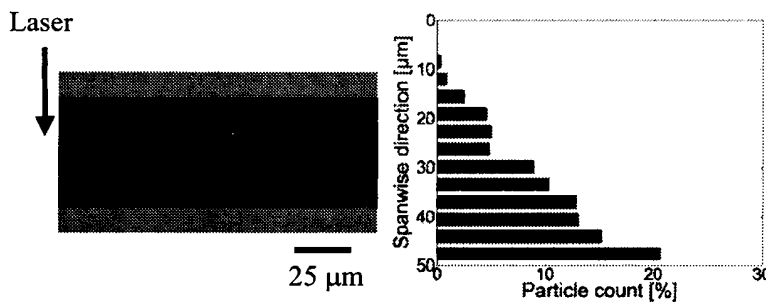

(b) Laser on

Fig. 3 Observed image in the downstream of irradiation area of the laser beam and particle distribution in spanwise direction

\section{4-2 高密度光·局所照射との比較}

図 4 に $15 \mathrm{~mm}$ の短距離流路に $145 \mathrm{~mW} / \mathrm{mm}^{2}$ の高密度光を 照射した場合との比較結果を示す.このとき，両者では流路 を通過する粒子が受ける光エネルギの総量はほぼ同等であ る. 高密度光・局所照射と同様に低密度光・広域照射でも同 様の粒子輸送を確認することができ, 理論との一致を示した また, 本結果は, 低コヒーレントかつ高強度な光を適応した 場合の粒子輸送の有効性を示すものと考えられる.この場合, 高精度な光軸設定や位置決めの装置や工程が不要となるた め, システムの大幅な簡易化が可能になる.

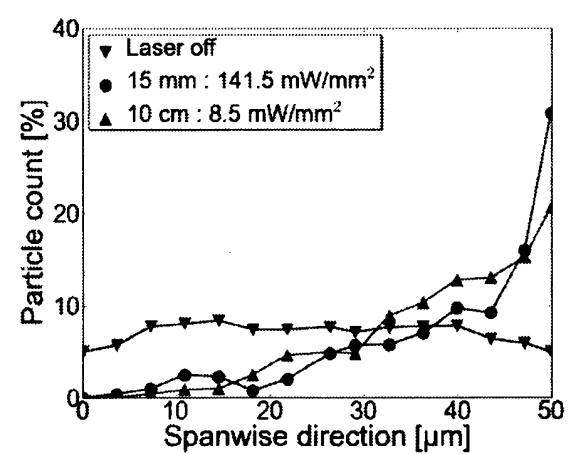

Fig. 4 Spanwise distribution of particle irradiated by large-area beam with different channel lengths

\section{4-3 粒子移動距離の粒子径依存性}

図 5 に粒径 $2 \mu \mathrm{m}$ と $5 \mu \mathrm{m}$ におけるスパン方向の粒子数分布 を示す. 流路壁面付近で粒子数が最大となる粒子 $5 \mu \mathrm{m}$ に対 して, 粒径 $2 \mu \mathrm{m}$ の場合ではスパン距離 $37 \mu \mathrm{m}$ 位置に最大值を 示し，粒子の移動距離が短いことが確認できる.小径粒子ほ ど光照射面積が狭くなり, 受ける光放射圧が弱くなるので, 移動距離は短くなる.よって, 本結果から異径粒子の分離の 可能性を示すことができた.

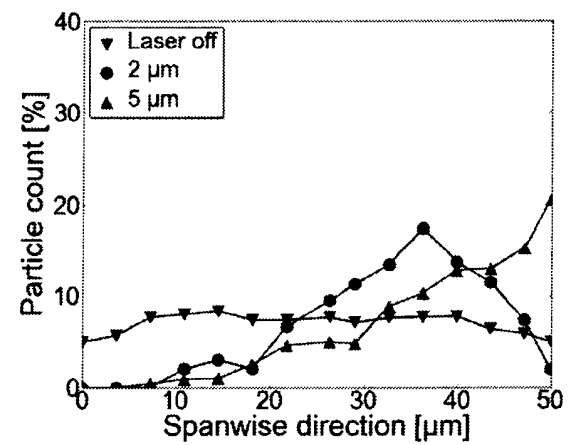

Fig. 5 Size sensitivity of particle distribution under effect of optical scattering force in long $(10 \mathrm{~cm})$ channel

\section{5. 結言}

本研究では，広域照射による光放射圧を用いた簡易的な微 粒子操作の可能性を検証するため, 長距離流路と低密度光照 射を組み合わせた粒子輸送デバイスを開発し，評価を行った． その有効性を確認するために, 高密度光による局所照射との 比較, 並びに粒径依存性を評価し, 理論との一致を得た. 本 結果より，提案する手法を用いた，光放射圧による簡易的な 微粒子操作が可能であることを示した。これにより，従来装 置では不可避である光軸調整を必要としない, 簡易粒子分離 技術の実現性を確認することができた。

\section{引用文献}

(1) F. B. Myers and L. P. Lee, Lab Chip, 8 (2008), 2015-2031.

(2) E. J. G. Perterman, F. Gittes and C. F. Schmidt, Biophys. J., 84 (2003), 1308-1316

(3) M. Motosuke, J. Shimakawa, D. Akutsu and S. Honami, J. Heat Transf., 134 (2012), 051025.

(4) A. Ishida, H. Toki, M. Motosuke and S. Honami, J. Them. Sci. Tech., 7 (2012), 475-486. 